体力科学 (2005) $54,15 \sim 16$

【教育講演 5 : 中高年登山の体力科学】

中高年登山体力科学

山 本 正 嘉
(鹿屋体育大学スポーツトレーニング教育研究センター)

\section{1. 登山と健康}

日本の登山人口はおよ光 460 万人と推定されてお り, 日本で最も愛好者の多いスポーツの一つであ る.特にこの 20 年間は，健康指向と自然指向を反映 し , 中高年の間で人気が高い . 登山もウオーキング と同樣，歩くという運動の延長上にあり，典型的な エアロビクスであるから，健康の維持増進という面 からも推奨できる.特に，ウオーキングなどをすで に行い，ある程度の体力が身についた人にとっては よい運動となる．たとえば次のようなメリットがあ る.

a . 心肺持久力に対するトレーニング効果

登山は荷物を背負って坂道を歩くので, ウオーキ ングでは運動強度が弱いと感じる人にはよい運動と なる．また，ウオーキングならば長く歩いても 1 日 に1〜2 時間以上歩くことは少ないが, 登山の場合 は最低でも $2 \sim 3$ 時間以上は歩くことがほとんどで ある.しかも大自然の中で歩くので，このような長 時間の運動を飽きずに続けられる．

b. 体脂肪の減量効果

上記のように，登山は非常に長時間にわたって行 われるエアロビクスであり, 運動強度もウオーキン グより高い.また登山のフィールドとなる山では， 低酸素や低温の影響により代謝が高進する。した がって登山は，体脂肪の減量効果に優れた効果があ る.

c . 脚の筋力に対するトレーニング効果

ウオーキングは健康の維持増進にとって多くのメ リットがある.しかし足りない部分も指摘されてい る.たとえば現在，高齢者の間で脚力の低下による 転倒が問題となっているが, ウオーキングをしてい るだけでは脚力低下は防ぎきれないとされる．いっ ぽう登山は，荷物を背負って坂道を上り下りする運 動なので, 脚力を強化する効果が期待できる .

以上のように，登山には多くのメリットがある . そこで, 登山を続けた場合に心身の健康にどのよう
な好影響があるかについてアンケート調査をしてみ た .中高年になってから登山を始めた 256 名を対象 として，「登山を始めてから健康上で良くなったこ と，悪くなったこと」について自由に記述してもら ったところ，約 7 割の人が何らかの点で良くなった と答えた .

弚の内容は多岐にわたるが，たとえば身体面では 「風邪を引きにくくなった」が最も多かった．これ は登山を励行することで免疫能力が高まったことを 示唆しており，医療費の軽減にも貢献していると予 想される . 精神的な面でも「ストレスの解消」「生 活の充実」をはじめ「性格の変化」「対人関係の変化」 といった変化が多くあげられており，精神的な健康 の改善にもよい影響を及ぼしていることが窺えた。

\section{2. 事故と障害の防止のために}

中高年が登山を行うことは健康によいが, 光の反 面で，登山者の増加に伴い事故も増加している. 現 在, 山岳事故の約 8 割は 40 歳以上の中高年によるも のであり，対策が急務である.事故の特徵としては， 技術的に容易な一般登山道の「下り」で転ぶもの(転 倒, 転落, 滑落)が目立って多く, 事故全体の約半 数を占めている. 登山道の下りでは脚に物理的に大 きな力がかかる(体重の 2 倍以上となることもある) が，これに耐えるだけの筋力が備わっていないこと が原因と考えられる。

7000 人以上の中高年登山者を対象に, 登山中に起 こるトラブルを尋ねた結果,「筋肉痛」「下りで脚が ガクガクになる」「膝の痛み」の 3 つが最も多く, いずれも該当率は 3 割を超えていた .これらワース 卜 3 のトラブルは, 脚筋力の弱い人が下りで起こし やすい，という共通点がある . 中高年の登山事故の 多くは下りで転ぶことによって起こると述べたが， この調査結果には光の前駆症状がはっきりと現れて いる.

このような事故を防ぐためには, 日常のトレーニ 
ングによって脚の筋力を強化しておく必要がある． この点について検討するために，同じアンケートで 日常生活でのトレ喜ーニング状況を尋ねた . 炎の結 果, 約 7 割という多数の人がトレーニングを実践し ており，光の種目は「ウオーキング」が圧倒的に多 く，約 8 割を占めていることがわかった .これらの ことを総合して考えると, 登山に必要な脚力は, 通 常のウオーキングによっては鍛えられない可能性が あるといえる .

この点について確かめるために, 日常におけるさ まざまなトレーニング種目と，登山中のトラブル発 生状況との関連を調べてみた，乥の結果，ウオーキ ングをはじめ, 自転車や水泳といった一般人が健康 のために行っている運動種目はいずれも，ワースト 3 のトラブルはもとより, 兴の他のトラブルもほと んど防げていないことがわかった .

いっぽう著者らが最近行った別の調査によれば， 「坂道でのウオーキング」や「筋カトレーニング」 には効果があることがわかった．つまり，ただ単に 運動をするのではなく，登山に必要な能力(特に脚 の筋力) 鍛える運動もあわせて行うことが重要と 考えられる .

登山事故と並んで考える必要があるのは，登山に よる障害の防止についてである．先に紹介した中高 年登山者256名に対する調査によると，登山を始め てから健康上で悪くなったことがあると答えた者は 約 1 割いたが，谷の内容はほとんどが膝関節痛また は腰痛だった .これらは荷物を背負って坂道を上り 下りするという，登山特有のストレスで起こるもの である .

ただし，登山によってこれらの症状が良くなった と答えている人もいるので, やり方のよしあしに依 存する部分が大きいと考えられる .このようなトラ ブルを防止するためには, $\mathrm{a}$ ：正しい歩行技術の修
得, $b$ : 身体をサポートする用具の使用, $c$ ：日常 における筋力トレーニング, $\mathrm{d}$ ：日常におけるコン ディショニング，の4つが重要である .

bについてはストック , サポーター, サポートタ イツ，靴のインソールなどの使用が有効である．c では, 膝関節痛の場合はスクワット運動, 腰痛の場 合は上体起こし運動が効果的である．dでは膝関節 痛に対しては大腿四頭筋, 腰痛に対しては腰背筋の ストレッチングを行う他，関節の軟骨形成を促進す るサプリメント(グルコサミンやコンドロイチンな ど)の服用が有効である .

\section{3. 生涯スポーツとしての登山の価値}

約4000名の中高年登山者を対象として，「登山時 の疲労度」にどのような要因が関係するかを調べた ところ, 年齢, 性別には全く関連が見られなかっ た．また，日常のトレーニングや登山の頻度が多い 人は疲労しにくい傾向を示した，光して，登山経験 については長くなるほど疲労しにくくなる傾向が見 られた .

これらのことは，登山は年齢や性別に関わらず， 普段からの心がけ(登山の励行と日常でのトレーニ ング)次第で, 生涯楽しめるスポーツであることを 意味している．日本は山国であり，全国に個性のあ る山がたくさんある .これらさまざまな山を巡るこ とは, 身体面での健康によいばかりでなく，精神面 でも大きな恵みをもたらしてくれるだろう．

これまで, ウオーキングや水泳といった運動につ いては, 健康との関わりについて数多くの研究が行 われ，実施上のガイドラインもほぼ確立されている． しかし, 登山に関するこのような観点からの研究は 非常に少ないのか現状である.生涯スポーツとして の登山をさらに定着させていくためにも , この方面 の研究が今後さらに発展することが望まれる . 